\title{
THE DISTRIBUTION OF INTRAVENOUSLY-INJECTED INULIN IN THE FLUIDS OF THE NERVOUS SYSTEM OF THE DOG AND RAT*
}

\author{
By ASHTON B. MORRISON $\dagger$
}

(From the Department of Pathology, Duke University School of Medicine)

(Submitted for publication January 29, 1959; accepted June 5, 1959)

In any quantitative study of the degree of damage to the blood-brain barrier, it is necessary to be able to measure the degree of permeability of the barrier to a substance which does not ordinarily pass through it. Bakay (1) employed $\mathrm{P}^{32}$ labeled inorganic phosphate for this purpose; he measured the amount of the substance taken up by the brain tissue of cats after injuries which caused damage to the barrier. Unfortunately, once inorganic phosphate passes through the blood-brain barrier, it is rapidly taken up by the nerve cells so that its absolute concentration in the tissue is no accurate measure of the degree of damage to the barrier. For the purpose of measuring the degree of this damage, it would be more advantageous to use a substance which, unlike $\mathrm{P}^{32}$ labeled inorganic phosphate, does not enter nerve cells once it has passed through the damaged barrier. Inulin, which has been used extensively in extracellular fluid measurements in other tissues, might serve for such studies. Unfortunately, there is no detailed account of the degree of penetration of nervous tissues by inulin in the living animal. This is surprising in view of the amount of information relating to the distribution of inulin in the fluids of other tissues such as muscle (2-5).

Allen (6) has determined the volume of distribution of inulin in tissue slices of brain by immersing them in solutions of inulin long enough for diffusion to take place and then estimating the inulin content of the slices. He found that about 14.5 per cent of the tissue consisted of fluid to which inulin had access; and, since this value

* This investigation was supported by a grant from the United States Public Health Service, National Institute for Arthritis and Metabolic Diseases (A-1375 C1).

$\dagger$ John and Mary R. Markle Scholar in Medical Science. Present address: Department of Pathology, University of Pennsylvania Medical School, Philadelphia, $\mathrm{Pa}$. agrees very well with values obtained for the extracellular fluid content of other tissues as measured using inulin (7), it seems reasonable to assume that inulin does not penetrate the cells of the nervous tissue to any greater extent than it penetrates the cells of the rest of the body. Allen's studies (6) did not throw any light on the way in which inulin was handled by the blood-brain barrier, although he remarked in his paper that inulin does not penetrate the blood-brain barrier. In much the same fashion, many others writing on the body fluids have made the statement or assumed that inulin does not enter the cerebrospinal fluid $(7,8)$. The fact that inulin does not enter the fluids of the gastrointestinal tract has been demonstrated (9) ; but, apart from an observation made by Swan, Madisso and Pitts in the course of a related study (10), little is recorded of its behavior with respect to fluids of the central nervous system. Substances similar to inulin in chemical composition such as fructose and sucrose have been shown to enter the brain slowly (11), and it might be presumed that inulin behaved in a similar fashion.

In order to explore the possibility of using inulin as a measure of the integrity of the blood-brain barrier and at the same time to obtain information about the nature of the extracellular fluids of the nervous system, the following study of the degree of penetration of inulin into the normal brain and spinal cord of dogs and rats was carried out. It also seemed convenient at this time to find out to what extent inulin entered the cerebrospinal fluid of dogs.

\section{METHODS}

The experiments were carried out on mongrel dogs and male rats of the Osborne-Mendel Strain.

The dogs which had been fasted overnight were bilaterally nephrectomized after anaesthesia had been induced with Nembutal ${ }^{\circledR}(.5 \mathrm{ml}$. per $\mathrm{Kg}$. body weight intravenously). After the withdrawal of a control sample 
TABLE I

Relationship between simultaneous extracellular fluid and cerebrospinal fluid inulin levels at end of each experiment on the dogs

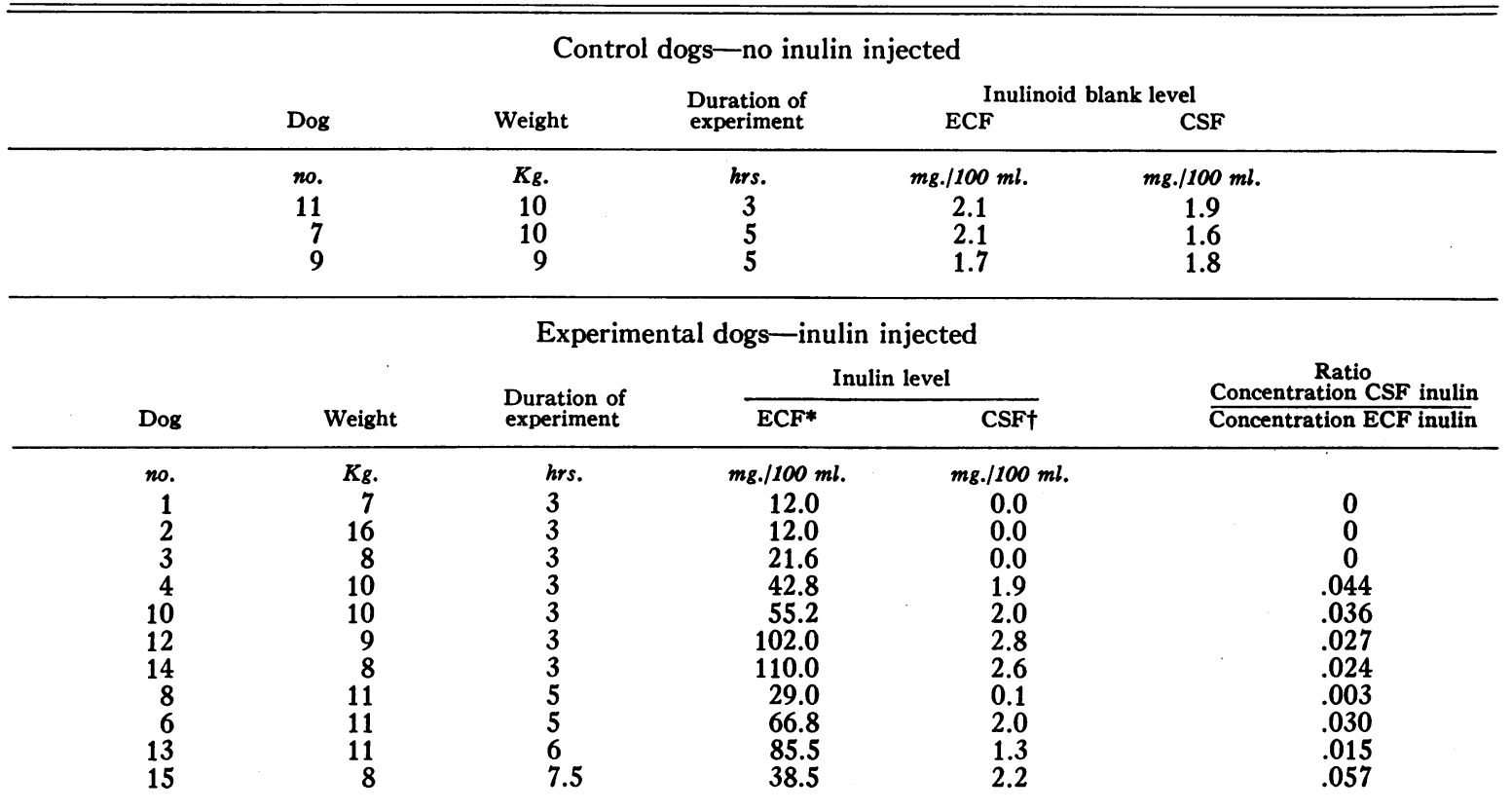

* This represents the difference between the total chromogen level at the end of the experiment and that found before the injection of inulin.

$\dagger$ This represents the difference between the total chromogen level in the CSF of each animal and the average blank value found in the control animal.

of blood, a solution of inulin was infused intravenously, the amount administered to each animal being chosen in such a way that the individual serum inulin levels, after equilibration in body fluids had taken place, were spread between values of $10 \mathrm{mg}$. per cent and $100 \mathrm{mg}$. per cent. In three dogs (Table I, Numbers 7, 9 and 11) no inulin was injected but the animals were subjected to all the other procedures.

At intervals varying from three to seven hours after the injections of inulin a sample of cerebrospinal fluid (CSF) was obtained from each dog and immediately following this, blood was obtained by cardiac puncture. The CSF was withdrawn by the introduction of a needle such as is used for lumbar puncture in humans into the cisterna cerebello-medullaris from the back of the neck. After the cardiac puncture each animal was killed by injecting Nembutal intravenously. Immediately after death in Animals 7 to 14, inclusive, the cranial vault was removed to expose the brain and the spinal cord was displayed by a rapid laminectomy. In each of the dogs dissected in this way, portions of cerebral cortex, white matter and spinal cord were removed, washed rapidly in a dish of $0.15 \mathrm{M}$ saline, dried quickly on filter paper, and placed in tared, stoppered tubes.

The eight male rats studied weighed about $250 \mathrm{Gm}$. each and were fasted during the night before the experiment but allowed water freely. A bilateral nephrectomy was carried out in each under ether anaesthesia and in six of them $1 \mathrm{ml}$. of a 2 per cent solution of inulin in $0.15 \mathrm{M}$ saline was injected intravenously. In two of the rats used as controls (Table II, Numbers 247 and 253), no inulin was injected but $1 \mathrm{ml}$. of the saline solution was used. Three hours after the inulin injection, blood was withdrawn from each rat by aortic puncture under anaesthesia, and the animal was killed. The cranial vault was removed in each animal, a piece of each cerebral hemisphere removed quickly, washed, dried on filter paper, and transferred to a tared, stoppered tube. It was not possible to procure samples of CSF in the rats nor was it easy to discriminate between white and gray matter as was done in the case of the dogs.

Preparation of samples. To a $1 \mathrm{ml}$ : aliquot of serum separated from each blood sample was added $15 \mathrm{ml}$. of distilled water, $2 \mathrm{ml}$. of a $0.3 \mathrm{M}$ solution of $\mathrm{Ba}(\mathrm{OH})_{2}$ and $2 \mathrm{ml}$. of a 5 per cent solution of $\mathrm{Zn}\left(\mathrm{SO}_{4}\right)_{2}$. The precipitate was removed by filtration and the resulting solution was analyzed for inulin. The CSF samples were treated similarly. After reweighing the tubes containing the tissues, $3 \mathrm{ml}$. of distilled water was added to each and the tissue well minced in it with a stirring rod. The resulting suspensions were kept overnight in the refrigerator and $3 \mathrm{ml}$. of a 20 per cent solution of trichloracetic acid was added to each of them; the resulting precipitate was removed by filtration. Aliquots of the filtrate were taken and analyzed for inulin.

Inulin method. Inulin was determined throughout by 
the resorcinol method for fructose of Bacon and Bell (12) as modified for inulin by Higashi and Peters (13).

Depending on whether serum and CSF or tissue was being analyzed for inulin, a suitable standard was used which had been treated in a similar fashion with respect to protein precipitant. The standards were prepared by appropriate dilution of the original inulin solution used for injection.

Recoveries. In order to estimate the sensitivity of the method for tissue inulin, recoveries were carried out. A piece of normal dog spinal cord weighing from 1 to 2 $\mathrm{Gm}$. was placed in each of six tared tubes and reweighed. Each sample was prepared for analysis in the same fashion described above for the tissues from animals. After filtration of the precipitated proteins, separate $2 \mathrm{ml}$. aliquots of the filtrates were taken and to them were added $2 \mathrm{ml}$. amounts of water in which had been dissolved $0.005 \mathrm{mg}$., $0.015 \mathrm{mg}$., $0.020 \mathrm{mg}$. and 0.025 mg. amounts of inulin, respectively. The resulting $4 \mathrm{ml}$. aliquots containing the added inulin were analyzed for inulin, using as a blank a further $2 \mathrm{ml}$. aliquot of each filtrate to which had been added $2 \mathrm{ml}$. of distilled water. The recoveries are set out in Table III. It can be seen that, as the added inulin rose above $0.02 \mathrm{mg}$. per $\mathrm{Gm}$. of tissue, the accuracy of the recovery was more satisfactory, being of the order of 105 per cent. This means that, where the serum inulin level was $20 \mathrm{mg}$. per cent, an estimation of the inulin space in the nervous tissue could be made if it exceeded 4 per cent of the wet weight of the tissue, with an error of about 5 per cent. Except in the case of Animal 8 (Table I), the serum level in the dogs was at least $50 \mathrm{mg}$. per cent, thus allowing a greater

\section{TABLE II}

Extracellular fluid inulin levels and inulin spaces of the nervous tissues in the rats

\begin{tabular}{|c|c|c|}
\hline \multicolumn{3}{|c|}{ Control animals-no inulin injected } \\
\hline \multirow[b]{2}{*}{ Rat } & \multicolumn{2}{|c|}{ Inulinoid blank } \\
\hline & ECF & $\begin{array}{c}\text { Nervous } \\
\text { tissue }\end{array}$ \\
\hline no. & $m g . / 100 \mathrm{ml}$ & $\underset{\text { tissue }}{\text { mg./100 } \mathrm{Gm} .}$ \\
\hline $\begin{array}{l}247 \\
253\end{array}$ & $\begin{array}{l}1.9 \\
1.7\end{array}$ & $\begin{array}{l}4.6 \\
4.2\end{array}$ \\
\hline
\end{tabular}

\begin{tabular}{cccc}
\multicolumn{4}{c}{ Experimental animals-inulin injected } \\
Rat & $\begin{array}{c}\text { ECF } \\
\text { inulin* }\end{array}$ & $\begin{array}{c}\text { Total inulin } \\
\text { chromogen of } \\
\text { nervous tissue }\end{array}$ & $\begin{array}{c}\text { Inulin } \\
\text { space }\end{array}$ \\
\hline no. & mg./100 ml. & mg./100 Gm. & $\begin{array}{c}\text { Gm./100 Gm. } \\
\text { tissue }\end{array}$ \\
246 & & 5.5 & 2.5 \\
248 & 44.5 & 5.8 & 3.3 \\
249 & 42.5 & 6.2 & 3.1 \\
251 & 56.0 & 6.0 & 3.3 \\
252 & 49.2 & 5.8 & 2.5 \\
\hline
\end{tabular}

* This represents the difference between the total chromogen level in the experimental animals and the blank chromogen found in the controls.

\begin{tabular}{cccc}
\multicolumn{5}{c}{ TABLE III } \\
Recoveries \\
\hline \hline \multirow{4}{*}{ Tissue } & $\begin{array}{c}\text { Inulin } \\
\text { added }\end{array}$ & $\begin{array}{c}\text { Inulin } \\
\text { recovered }\end{array}$ & Recovery \\
\hline & $\begin{array}{c}\text { mg./Gm. } \\
\text { tissue }\end{array}$ & $\begin{array}{c}\text { mg./Gm. } \\
\text { tissue }\end{array}$ & per cent \\
& 0.008 & 0.009 & 111 \\
1 & 0.011 & 0.012 & 109 \\
2 & 0.011 & 0.013 & 118 \\
3 & 0.038 & 0.040 & 103 \\
4 & 0.030 & 0.031 & 103 \\
5 & 0.025 & 0.026 & 104 \\
6 & & & \\
\hline
\end{tabular}

accuracy in the determination of smaller inulin spaces. It is evident from the recovery figures that there was a tendency to overestimate the inulin content of the tissue and therefore the inulin space.

Calculations. The difference between the total serum chromogen at the end of the experiment and the inulinoid chromogen blank on the serum drawn at the beginning, before the inulin injection, gave the serum level of the injected inulin. The concentration of inulin in the extracellular fluids (ECF) which was presumably the same as that in serum water was derived from that found in the blood serum by multiplying it by the factor 1.07 .

The total chromogen present in each sample of tissue was calculated, taking into account the water content of the tissue which was assumed to be 78 per cent of its total weight (6). From this figure the chromogen content per $100 \mathrm{Gm}$. wet tissue was obtained. Similar values were obtained in the tissues from the control animals and these figures represented the chromogen blank. By subtracting the average value of the tissue chromogen blank obtained in the control animals from the total chromogen content of each tissue in the experimentals, a figure was obtained which represented the content of injected inulin in each sample of tissue. From the inulin content of the nervous tissue in each animal and its concentration in ECF the inulin space of the tissue was calculated by simple division and expressed as a mass of fluid in grams for unit weight of the tissue.

RESULTS

\section{Serum and cerebrospinal fuid levels}

Table I sets out the simultaneous ECF and CSF levels of inulin in each dog. The concentration of ECF inulin has been derived from the serum inulin as described above. In the animals with the higher ECF inulin concentrations there appeared to be slightly higher levels in the CSF, but the relationship was erratic. In Animals 1, 2, $3,4,10,12$ and 14, the experiment was continued for three hours and, when there was more than $40 \mathrm{mg}$. per cent of inulin in the ECF, a slight increase in the CSF inulin was detected; but fur- 


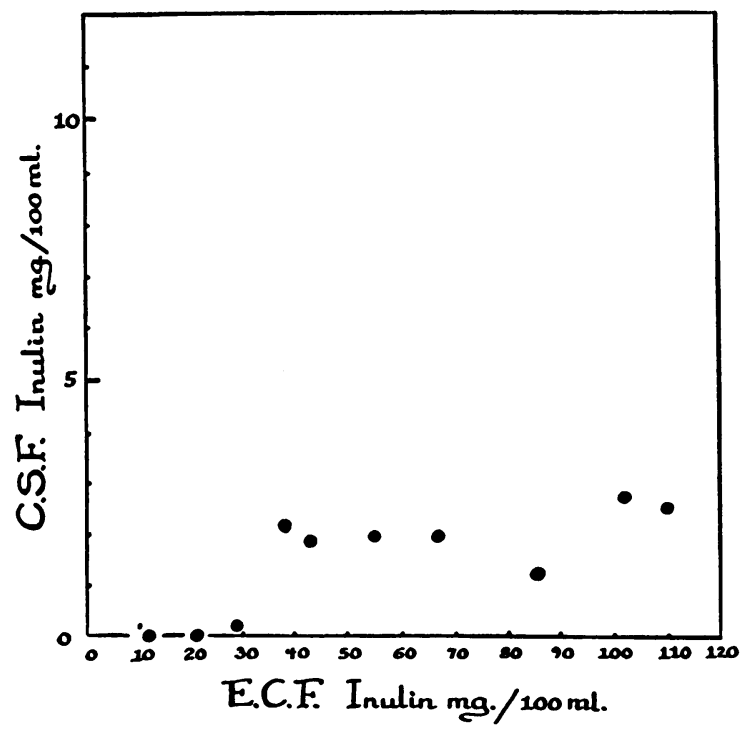

Fig. 1. Simultaneous Cerebrospinal Fluid (CSF) and Extracellular Fluid Inulin (ECF)

Concentrations at the end of each experiment.

ther elevation of the ECF level to values approaching $100 \mathrm{mg}$. per cent did not seem to produce any significant increase in the concentration in the $\mathrm{CSF}$. Some of these effects may have resulted from overestimation of the inulin at low concentrations due to the relative insensitivity of the method.

In order to test the effect of a more prolonged experiment, the period between the introduction of the inulin and the withdrawal of the CSF was extended as in Animals 6, 8,13 and 15. Here, although the ECF inulin levels were comparable to those prevailing in the three hour experiments, no striking increases were observed in the inulin concentration of the CSF of the animals. The variation in the ratio $\frac{\text { Concentration of inulin CSF }}{\text { Concentration of inulin ECF }}$ was a further indication of the erratic relationship between the inulin levels of the two fluids. Neither extension of the experimental period nor increase in the serum levels seemed to bring about any consistent changes in the ratio over the range of concentrations studied, although the figures suggest that inulin entered the CSF to a slightly greater degree when the ECF level was higher. The relationship between the level of inulin in the ECF and that in the CSF is set out in graphical form in Figure 1. It is easily seen that when the inulin level of the ECF rose above $30 \mathrm{mg}$. per cent small but detectable quantities of inulin were present in the CSF. At the levels of ECF inu- lin studied the concentrations of it in the CSF were certainly very much lower than in the ECF.

\section{Inulin space of the nervous tissues}

In Tables IV, V and VI are set out the data pertaining to the inulin space of the spinal cord, white matter and gray matter of each of the dogs studied. The inulinoid blanks found in the same tissues of the control animals (Dogs $7,9,11)$ are at the top of each table. The inulin space in each piece of tissue analyzed has been calculated on the assumption that the average inulinoid value for that particular tissue in the control animals can be used as a chromogen blank to subtract from the total chromogen value in the same tissue of the experimental animal. The inulin space is set out in the right hand column of each table.

It can be seen from Table IV that the inulin space for the spinal cord was, at the most, 2 per cent of the tissue weight. In only one animal (No. 12) did the inulin space exceed that value in both samples of spinal cord and there the inulin space was not greater than 4 per cent of the

TABLE IV

Inulin space of the spinal cord in the dogs

\begin{tabular}{|c|c|c|c|c|}
\hline \multicolumn{5}{|c|}{ Control animals-no inulin injected } \\
\hline \multicolumn{3}{|c|}{ Dog } & \multicolumn{2}{|c|}{$\begin{array}{l}\text { Inulinoid } \\
\text { substance }\end{array}$} \\
\hline \multicolumn{3}{|c|}{ no. } & \multicolumn{2}{|c|}{$\begin{array}{l}\text { mg. } / 100 \mathrm{Gm} \\
\text { spinal cord }\end{array}$} \\
\hline \multicolumn{2}{|r|}{7} & $\begin{array}{l}\text { Sample A } \\
\text { Sample B }\end{array}$ & \multicolumn{2}{|c|}{$\begin{array}{l}3.9 \\
3.7\end{array}$} \\
\hline & 9 & $\begin{array}{l}\text { Sample A } \\
\text { Sample B }\end{array}$ & \multicolumn{2}{|c|}{$\begin{array}{l}3.5 \\
2.9\end{array}$} \\
\hline & 11 & $\begin{array}{l}\text { Sample A } \\
\text { Sample B }\end{array}$ & \multicolumn{2}{|c|}{$\begin{array}{l}3.8 \\
3.4\end{array}$} \\
\hline \multicolumn{5}{|c|}{ Experimental animals-inulin injected } \\
\hline Dog & & & $\begin{array}{l}\text { Total inulin } \\
\text { chromogen }\end{array}$ & $\begin{array}{l}\text { Inulin } \\
\text { space }\end{array}$ \\
\hline no. & \multirow{2}{*}{\multicolumn{2}{|c|}{$\begin{array}{l}\text { Sample A } \\
\text { Sample B }\end{array}$}} & $\begin{array}{l}m g_{.} / 100 \mathrm{Gm} \\
\text { spinal cord }\end{array}$ & $\underset{\text { spinal cord }}{\mathrm{G} m . / 100 \mathrm{Gm}}$ \\
\hline 8 & & & $\begin{array}{l}3.5 \\
4.0\end{array}$ & $\begin{array}{l}0.0 \\
1.8\end{array}$ \\
\hline 10 & \multicolumn{2}{|c|}{$\begin{array}{l}\text { Sample A } \\
\text { Sample B }\end{array}$} & $\begin{array}{l}3.7 \\
4.9\end{array}$ & $\begin{array}{l}0.4 \\
2.5\end{array}$ \\
\hline 12 & \multicolumn{2}{|c|}{$\begin{array}{l}\text { Sample A } \\
\text { Sample B }\end{array}$} & $\begin{array}{l}7.8 \\
6.9\end{array}$ & $\begin{array}{l}4.2 \\
3.3\end{array}$ \\
\hline 13 & \multicolumn{2}{|c|}{$\begin{array}{l}\text { Sample A } \\
\text { Sample B } \\
\text { Sample C }\end{array}$} & $\begin{array}{l}4.7 \\
4.9 \\
6.0\end{array}$ & $\begin{array}{l}1.4 \\
1.6 \\
2.9\end{array}$ \\
\hline 14 & \multicolumn{2}{|c|}{$\begin{array}{l}\text { Sample A } \\
\text { Sample B }\end{array}$} & $\begin{array}{l}5.5 \\
5.7\end{array}$ & $\begin{array}{l}1.8 \\
2.0\end{array}$ \\
\hline
\end{tabular}


weight of the tissue. Values of a similar order of magnitude were found for the inulin spaces in the case of both white and gray matter (Tables V and VI).

If the assumption is made that the amount of inulin in each piece of tissue, and thus the inulin space, was being underestimated by the amount of the inulinoid blank value, then a figure, which represents the extreme limits of such an underestimated inulin space, may be calculated. Even on this basis the inulin space represented only about 5 per cent of the tissue weight and only rarely did it exceed 10 per cent by weight of the tissue.

Comparison of the blank values obtained in the three control animals showed a moderate variation in individual animals (Tables IV, V and VI, Animals 7, 9 and 11). The variation in the different tissues examined was consistent in any one

TABLE V

Inulin space of cerebral white matter in dogs

\begin{tabular}{|c|c|c|c|c|}
\hline \multicolumn{5}{|c|}{ Control animals-no inulin injected } \\
\hline \multicolumn{3}{|c|}{ Dog } & \multicolumn{2}{|c|}{$\begin{array}{l}\text { Inulinoid } \\
\text { substance }\end{array}$} \\
\hline \multicolumn{3}{|c|}{ no. } & \multicolumn{2}{|c|}{$\begin{array}{l}m g . / 100 \mathrm{Gm} . \\
\text { white matter }\end{array}$} \\
\hline & 7 & $\begin{array}{l}\text { Sample A } \\
\text { Sample B } \\
\text { Sample C }\end{array}$ & \multicolumn{2}{|c|}{$\begin{array}{l}4.4 \\
4.9 \\
4.5\end{array}$} \\
\hline & 9 & $\begin{array}{l}\text { Sample A } \\
\text { Sample B } \\
\text { Sample C }\end{array}$ & \multicolumn{2}{|c|}{$\begin{array}{l}4.3 \\
4.9 \\
4.8\end{array}$} \\
\hline & 11 & $\begin{array}{l}\text { Sample A } \\
\text { Sample B } \\
\text { Sample C }\end{array}$ & \multicolumn{2}{|c|}{$\begin{array}{l}4.2 \\
5.0 \\
5.3\end{array}$} \\
\hline \multicolumn{5}{|c|}{ Experimental animals-inulin injected } \\
\hline Dog & & & $\begin{array}{l}\text { Total inulin } \\
\text { chromogen }\end{array}$ & $\begin{array}{l}\text { Inulin } \\
\text { space }\end{array}$ \\
\hline no. & & $\begin{array}{l}m g . / 100 \mathrm{Gm} \\
\text { white matter }\end{array}$ & $\begin{array}{l}\text { Gm. } / 100 \mathrm{Gm} \\
\text { white matter }\end{array}$ \\
\hline 8 & \multicolumn{2}{|c|}{$\begin{array}{l}\text { Sample A } \\
\text { Sample B }\end{array}$} & $\begin{array}{l}5.0 \\
5.1\end{array}$ & $\begin{array}{l}1.2 \\
1.4\end{array}$ \\
\hline 10 & \multicolumn{2}{|c|}{$\begin{array}{l}\text { Sample A } \\
\text { Sample B } \\
\text { Sample C }\end{array}$} & $\begin{array}{l}5.8 \\
4.9 \\
5.0\end{array}$ & $\begin{array}{l}2.0 \\
0.4 \\
0.5\end{array}$ \\
\hline 12 & \multicolumn{2}{|c|}{$\begin{array}{l}\text { Sample A } \\
\text { Sample B }\end{array}$} & $\begin{array}{l}6.2 \\
8.1\end{array}$ & $\begin{array}{l}1.4 \\
3.3\end{array}$ \\
\hline 13 & \multicolumn{2}{|c|}{$\begin{array}{l}\text { Sample A } \\
\text { Sample B }\end{array}$} & $\begin{array}{l}8.4 \\
5.6\end{array}$ & $\begin{array}{l}4.3 \\
1.0\end{array}$ \\
\hline 14 & \multicolumn{2}{|c|}{ Sample A } & 4.9 & 0.2 \\
\hline
\end{tabular}

TABLE VI

Inulin space of the gray matter in dogs

\begin{tabular}{ccc}
\hline \multicolumn{2}{c}{ Control animals-no inulin injected } \\
Dog & & $\begin{array}{c}\text { Inulinoid } \\
\text { substance }\end{array}$ \\
\hline no. & & $\begin{array}{c}\text { mg./100 Gm. } \\
\text { gray matter }\end{array}$ \\
7 & Sample A & 4.6 \\
& Sample B & 5.2 \\
& Sample C & 4.9 \\
9 & Sample A & 4.4 \\
& Sample B & 4.6 \\
& Sample C & 4.7 \\
11 & Sample A & 4.7 \\
& Sample B & 5.3 \\
& Sample C & 5.2 \\
\hline
\end{tabular}

\begin{tabular}{|c|c|c|c|}
\hline \multicolumn{4}{|c|}{ Experimental animals-inulin injected } \\
\hline Dog & & $\begin{array}{l}\text { Total inulin } \\
\text { chromogen }\end{array}$ & $\underset{\text { space }}{\text { Inulin }}$ \\
\hline no. & & $\underset{\text { gray matter }}{\text { mg. } / 100 \mathrm{Gm}}$ & $\begin{array}{l}\mathrm{Gm} . / 100 \mathrm{Gm} \\
\text { gray matter }\end{array}$ \\
\hline 8 & $\begin{array}{l}\text { Sample A } \\
\text { Sample B } \\
\text { Sample C }\end{array}$ & $\begin{array}{l}5.8 \\
5.4 \\
6.0\end{array}$ & $\begin{array}{l}3.4 \\
2.1 \\
4.1\end{array}$ \\
\hline 10 & $\begin{array}{l}\text { Sample A } \\
\text { Sample B } \\
\text { Sample C }\end{array}$ & $\begin{array}{l}5.1 \\
5.7 \\
5.2\end{array}$ & $\begin{array}{l}0.5 \\
1.6 \\
0.7\end{array}$ \\
\hline 12 & $\begin{array}{l}\text { Sample A } \\
\text { Sample B } \\
\text { Sample C }\end{array}$ & $\begin{array}{l}5.9 \\
5.5 \\
5.8\end{array}$ & $\begin{array}{l}1.1 \\
0.7 \\
1.0\end{array}$ \\
\hline 13 & $\begin{array}{l}\text { Sample A } \\
\text { Sample B }\end{array}$ & $\begin{array}{l}9.1 \\
7.6\end{array}$ & $\begin{array}{l}5.0 \\
3.3\end{array}$ \\
\hline 14 & $\begin{array}{l}\text { Sample A } \\
\text { Sample B } \\
\text { Sample C }\end{array}$ & $\begin{array}{l}6.6 \\
6.3 \\
6.1\end{array}$ & $\begin{array}{l}1.6 \\
1.4 \\
1.2\end{array}$ \\
\hline
\end{tabular}

animal, being highest in the cortex and lowest in the spinal cord. The intermediate position of the white matter may be related to the fact that it was virtually impossible to obtain white matter without adherent gray cortex. The extent to which this variation in the blank chromogen value of the different tissues may be due to the proportion of each tissue that was made up of blood from the vascular bed cannot be determined, as no estimation of the amount of blood remaining in the individual tissues was carried out.

\section{Rat nervous tissue}

The data obtained for the rats are set out in Table II. The figures obtained apply to the cerebral hemispheres of the rats without reference to 
predominance of gray or white matter in the sample taken. The values for the inulin sprces of the tissue were calculated in the same way as in the dogs. The values for the inulinoid content of the cerebral tissues of the control uninjected rats were of the same order as those found in the dogs, expressed per gram of tissue. The inulin space of the rat tissues varied from 1 to 3 per cent of the wet weight of the tissues. These values again are of the same order as those found in the various nervous tissues of the dogs. In the rats, as can be seen from the table, no attempt was made to vary the serum level of inulin from one rat to another, as had been done in the case of the dogs. The experiments in the rats were continued for only three hours, since it has been demonstrated $(3,6,14)$ that inulin has diffused fairly completely into the ECF of the rat by the end of three hours. It was felt for this reason that the inulin content of the nervous tissues, after a three hour equilibration period in the rat, should be as satisfactory a measure of the inulin space as in other tissues.

\section{DISCUSSION}

These experimental results demonstrate that the blood-CSF barrier, whatever it may be, greatly restricted the passage of inulin from the blood into the CSF of the cisterna cerebello-medullaris. A very significant difference was obvious in the levels of inulin in the blood serum and in the CSF in the ranges studied, although data have not been collected for serum inulin levels above $103 \mathrm{mg}$. per cent. The results suggest that as the serum level of inulin was raised the amount of it found in the CSF increased slightly, but no consistent relationship was apparent from the limited data available here. Extension of the equilibration time available for the free diffusion of inulin certainly appeared to make little difference in the CSF levels attained.

The small amounts of inulin found in the CSF of the animals in which the highest serum levels had been established may have come across the barrier or may even have diffused through the venous sinuses of the cranium. The relative impermeability of the venous sinus channels and the arachnoid granulations to inulin passing in the reverse direction, that is from the CSF to the blood, has been established by Davson, who injected inulin into the CSF of rabbits and measured its very slow disappearance from the fluid into the blood stream (15).

One disadvantage that is incurred in measuring, as was done here, the inulin content of the fluid withdrawn from the cisterna cerebello-medullaris is that it may not be representative of the fluid as a whole; fluid from the ventricles may contain more inulin which has passed across the choroid plexuses during the experimental period than that fluid already present in the cisterna and available for analysis, although the opposite state of affairs is more likely to be the case. In order to determine how quickly mixing of the ventricular and cisternal fluids may occur, some idea of the rate of formation of ventricular fluid is necessary. The rate of formation and flow studied by the rate of disappearance of substances injected into the CSF suggests that 0.3 per cent of the fluid is renewed per minute by formation in the ventricle (16). More recent studies by Vasilevskii, who determined the volume rate of movement of CSF in dogs by a mathematical analysis of the concentration curves for the transport of an indicator, provide support for this figure (17). According to Vasilevskii (17), 96 to $129 \mathrm{ml}$. of CSF flows from the ventricles of the dog in 24 hours and the CSF is exchanged not less than 10 times per day. These figures suggest that in the dog at any rate the concentrations of inulin present in the cisternal fluid after an equilibration period of at least three hours are probably not greatly different in order of magnitude from those in the ventricles close to the plexus.

The ratio $\frac{\text { Concentration in CSF }}{\text { Concentration in serum }}$ has been measured for sucrose by Davson, and the value he found was 0.022 (18). In the experiments reported here, a figure of the same order of magnitude was obtained for the ratio in the case of inulin, when allowance has been made for the inulinoid blank values of both serum and CSF. It is difficult to make an accurate comparison of the ratios for sucrose and inulin, since the figure calculated for sucrose by Davson prevailed after the serum level had been maintained at a steady level for a period of time (18), while in the experiments reported here, the serum level of inulin 
was presumably at its peak just after injection and slowly declined as the inulin diffused through the ECF of the dog from the time of injection.

From the results of the tissue analysis, it can be seen that just as the blood-CSF barrier restrained the passage of inulin, so the blood-brain barrier also seemed to impair its free diffusion. The low values discovered for the inulin space of the nervous tissue are consistent with the view that the inulin may be confined almost entirely to the blood vascular channels. It has been shown that the average content of blood in the brain of the dog occupies 8.3 per cent of the weight of the tissue (19). Assuming that half of this blood is serum, then 4.1 per cent of the nervous tissue is occupied by serum. This figure is of the same order of magnitude as the values obtained in these experiments for the inulin space of the nervous tissue. The similarity of these two values suggests that inulin diffuses through a space in the nervous tissue closely corresponding in size to that of the blood and most likely confined to the same anatomical location. The low values for the inulin space found in these in vivo experiments are in sharp contrast to the values of around 15 per cent of the wet weight of the nervous tissue found by Allen (6). His experiments were carried out on tissue slices of brain and the results can in no way be regarded as inconsistent with ours. They suggest, indeed, that inulin, if it is not imprisoned in the blood vessels by the blood-brain barrier, is free to diffuse more freely through the brain tissue. It is impossible to be sure through what particular fluid phase such diffusion takes place but, considering the extent of the diffusion in Allen's experiments (6), it appears to be similar in extent to what would be regarded as ECF in other tissues. Although Allen found evidence that the inulin entered nerve cells to some extent toward the end of his incubation periods, it is probable that such a finding was more a result of the state of the cells in the tissue slice than a reflection on the behavior of nerve cells in vivo with respect to inulin.

The CSF has been described as a transcellular fluid $(7,20)$ but, as Manery has pointed out (21), it is still part of the body's extracellular fluids and may more specificially be representative in composition of the fluid which bathes the nerve cells, that is, the true ECF of the nervous system or its equivalent. The relative inability of inulin to permeate either the CSF or the tissues of the nervous system, as demonstrated here, may reflect the biological identity of those fluids suggested by Manery (21).

The possibility that the ECF, as it appears to exist in other tissues, is not present in the nervous system has been suggested by Lumsden $(22,23)$. He contends that the area which makes up the neuropil and lies between the endothelium of the brain capillaries and the nerve cells themselves, consists of a glue-like stuff which is cytoplasm contained in processes of the astrocytes. The nutrients and other substances required by the nerve cells presumably pass from the vascular system across the protoplasmic neuropil either by a process of active transport or by simple diffusion. In the same way the astrocytic processes making up the neuropil may be the system responsible for confining many substances including inulin to the vascular bed of the brain. If this is so then inulin may not permeate the brain fluids because it is unable to pass into and through the cytoplasmic material of the neuropil, just as it does not enter other tissue cells. The means by which this is accomplished is unknown, but it may represent an active transport process on the part of the astrocytes or their processes. The entry of inulin into 14.5 per cent by weight of a tissue slice of brain, as reported by Allen (6), may be regarded in the light of this hypothesis as the result of a failure of the process of active transport under conditions such as exist in a tissue slice, where the oxygen supply of the neuroglia and their processes may be impaired. The results presented here concerning the relative inability of the inulin to penetrate the fluids of the nervous system indicate that the nervous system lacks an inulin space such as exists in other tissues. As it is known that the thiocyanate space in the brain tissue is much smaller than in other tissues (23), the results of these experiments with inulin may be confirmatory evidence of the absence of an ECF phase in the brain comparable to that obtaining in other tissues.

Eichelberger and Richter (24) have analyzed the brain of the dog for chloride and sodium and have calculated its ECF volume, assuming that the 
chloride and sodium are extracellular ions. On this basis, they find that the ECF volume of nervous tissue is 30 per cent of the wet weight of the tissue when chloride is the reference ion and 35 per cent when sodium is used as reference. The great discrepancy between the chloride and sodium spaces of nervous tissue as determined by Eichelberger and Richter on the one hand, and the inulin space derived from our experimental results on the other, serves to emphasize the fact that inulin and the other substances used to determine ECF volume in tissues and in the whole organism measure very different things. Quite apart from these considerations, the extreme degree of impermeability of the fluids of the central nervous system to inulin may well be a factor in its small volume of distribution relative to all the other substances used to measure ECF volume in the whole animal.

Inulin is, then, a substance which is probably confined to the blood vascular system in the central nervous system; and the measurement of its content in nervous tissue may well be of use in assessing the degree of damage to the blood-brain barrier. Further study of the relationship of the blood-brain barrier and the ECF of the central nervous system, using methods and substances similar to those used here, may provide further quantitative data on the nature of the fluids of the central nervous system and their relationship to the CSF.

\section{SUMMARY}

Inulin was injected intravenously into bilaterally-nephrectomized dogs and rats and, after intervals lasting at least three hours, the cerebrospinal fluid inulin concentration was compared with that of the serum.

Analyses of the gray matter, white matter and spinal cord for inulin were carried out after sacrifice and the inulin space of the tissue estimated.

Under the conditions of the experiment, inulin penetrated the blood-cerebrospinal fluid barrier of the dog to a slight extent. It was not able to cross the blood-brain barrier freely, and the in vivo inulin space of nervous tissue was less than 5 per cent of the wet weight of the tissue. The inulin may have been restricted to the blood vascular system either because it was unable to pass across the capillaries of the brain or because a fluid phase corresponding to the extracellular fluid in other tissues does not exist as such in the nervous system.

\section{ACKNOWLEDGMENTS}

It is a great pleasure to thank Dr. George Margolis for his helpful comments and suggestions during the whole course of this work and Dr. Wiley D. Forbus for his help and criticism in the preparation of the manuscript.

\section{REFERENCES}

1. Bakay, L. Studies on blood-brain barrier with radioactive phosphorus. V. Effect of cerebral injuries and infarction on the barrier. Arch. Neurol. Psychiat. (Chicago) 1955, 73, 2.

2. Mokotoff, R., Ross, G., and Leiter, L. The electrolyte content of skeletal muscle in congestive heart failure; a comparison of results with inulin and chloride as reference standards for extracellular water. J. clin. Invest. 1952, 31, 291.

3. Ledingham, J. M. The distribution of water, sodium, and potassium in heart and skeletal muscle in experimental renal hypertension in rats. Clin. Sci. 1953, $12,337$.

4. Turner, L. B., and Levitt, M. F. The extracellular compartment; a comparison of the chloride and inulin spaces. J. Mt. Sinai Hosp. 1953, 19, 653.

5. White, H. L., and Rolf, D. Inulin space as a function of equilibration time. Amer. J. Physiol. 1956, 185, 152.

6. Allen, J. N. Extracellular space in the central nervous system. Arch. Neurol. Psychiat. (Chicago) 1955, 73, 241.

7. Elkinton, J. R., and Danowski, T. S. The Body Fluids. Baltimore, The Williams and Wilkins Co., 1955, p. 77.

8. Welt, L. G. Clinical Disorders of Hydration and Acid-Base Equilibrium. Boston, Little, Brown and Co., 1955, p. 15.

9. Finkenstaedt, J. F., O'Meara, M. P., and Merrill, J. P. Observations on the volume of distribution of inulin in anuric subjects. J. clin. Invest. 1953, 32, 209.

10. Swan, R. C., Madisso, H., and Pitts, R. F. Measurement of extracellular fluid volume in nephrectomized dogs. J. clin. Invest. 1954, 33, 1447.

11. Gregersen, M. I., and Wright, L. The effect of intravenous injection of sucrose and glucose upon the reducing power of cerebrospinal fluid, before and after hydrolysis. Amer. J. Physiol. 1935, 112, 97.

12. Bacon, J. S. D., and Bell, D. J. Fructose and glucose in the blood of the foetal sheep. Biochem. J. 1948, 42, 397. 
13. Higashi, A., and Peters, L. A rapid colorimetric method for the determination of inulin in plasma and urine. J. Lab. clin Med. 1950, 35, 475.

14. McCance, R. A., and Morrison, A. B. The effects of equal and limited rations of water, and of 1,2 , and 3 per cent solutions of sodium chloride on partially-nephrectomized and normal rats. Quart. J. exp. Physiol. 1956, 41, 365.

15. Davson, $H$. The rates of disappearance of substances injected into the subarachnoid space of rabbits (abstract). J. Physiol. 1955, 128, 52P.

16. Davson, H. Physiology of the Ocular and Cerebrospinal Fluids. Boston, Little, Brown and Co., 1956, p. 134.

17. Vasilevskii, N. N. On the volume rate of circulation of the cerebrospinal fluid. Sechenov J. Physiol. 1957, 43, 698 .

18. Davson, H. Physiology of the Ocular and Cerebrospinal Fluids. Boston, Little, Brown and Co., 1956 , p. 117

19. Weil, A., Zeiss, F. R., and Cleveland, D. A. The determination of the amount of blood in the central nervous system after ingestion of hypertonic solutions. Amer. J. Physiol. 1931, 98, 363.

20. Edelman, I. S., Olney, J. M., James, A. H., Brooks, L., and Moore, F. D. Body composition: Studies in the human body by the dilution principle. Science 1952, 115, 447.

21. Manery, J. F. Water and electrolyte metabolism. Physiol. Rev. 1954, 34, 334.

22. Lumsden, C. E. The cytology and cell physiology of the neuroglia and of the connective tissue in the brain with reference to the blood-brain barrier (abstract). Excerpta med. (Amst.), Sect. VIII $1955,8,832$.

23. Lumsden, C. E. Histological and histochemical aspects of normal neuroglia cells in Biology of Neuroglia, W. F. Windle, Ed. Springfield, Ill., Charles C Thomas, 1958, p. 141.

24. Eichelberger, L., and Richter, R. B. Water, nitrogen, and electrolyte concentration in brain. J. biol. Chem. 1944, 154, 21. 